\title{
Migration and Social Replacement Incomes: How to Protect Low-Income Workers in the Industrialized Countries against the Forces of Globalization and Market Integration
}

Hans-Werner Sinn

From: International Tax and Public Finance 12, 2005, pp. 375-393

Electronic reprint 2006-02

May 2006

Department of EconomicsUniversity of Munich

Volkswirtschaftliche Fakultät

Ludwig-Maximilians-Universität München

Online at http://epub.ub.uni-muenchen.de 


\title{
Migration and Social Replacement Incomes: How to Protect Low-Income Workers in the Industrialized Countries Against the Forces of Globalization and Market Integration
}

HANS-WERNER SINN

sinn@ifo.de

Ifo Institute for Economic Research, University of Munich, 81679 Munich, Germany

\begin{abstract}
This paper discusses how an industrialized country could defend the living standard of its unskilled workers against the wage competition from immigrants. It shows that fixing social replacement incomes implies migration into unemployment. Defending wages with replacement incomes brings about first order efficiency losses that approximate the budget cost of the government. By contrast, wage subsidies involve much smaller welfare losses. While the exclusion of migrants from a national wage replacement program does not avoid the distortions in labor migration, the (temporary) exclusion of migrants from a national wage subsidy program makes it possible to reach the first best migration pattern despite the preservation of the welfare state.
\end{abstract}

Keywords: migration, unemployment, welfare

JEL Code: F15, F22, I38, H5, J61

\section{Introduction}

The world is integrating at a rapid pace. Since China and India have decided to participate in world trade, since the Iron Curtain has fallen, since the EU has integrated its internal market and expanded to the east, and since NAFTA has opened the US to trade with Mexico, the relative factor endowments in the market economies linked by trade have changed dramatically. Capital has become a scarce factor of production, and unskilled labor has become an abundant factor, the scapegoat of an otherwise beneficial economic development process. The integration of markets is reaping gains from trade, but due to the forces of factor price equalization these gains are accompanied by significant income losses of the working classes in the western countries, at least against the trend that otherwise would have prevailed. The achievements of a hundred years of social democracy are at risk.

In principle, the forces that put pressure on the wages of less qualified workers in the industrialized countries already come into operation via Heckscher-Ohlin type trade specialization and via capital movements. However, in many countries they are reinforced by migration processes triggered by huge wage differences. The east west migration in Europe 
that has taken place since the fall of the Iron Curtain and will continue in the years to come is an example. The average wage of the about 75 million people from central eastern Europe that joined the EU in 2004 is about one fifth of the EU average and about one seventh of the west German average. ${ }^{1}$ After a transition period not to last longer than until 2010 workers from the new EU countries will be able to offer their services in any of the old EU countries.

Ordinary workers in the industrialized countries are afraid of what will happen, and their fears may well be justified. They will not belong to the winners of this period of economic development. The winners are capital owners and skilled workers. It is true that market integration is likely to bring about gains from trade, but there are gains from trade only in the sense that the winners will gain more than the losers will lose. Gains from trade do not come about as Pareto improvements, but rather as Kaldor type gains where the winners could compensate the losers although they do not normally do so.

From a social perspective, this is truly disquieting. Thus it is understandable that the losers appeal to the welfare state to compensate them. The welfare state, however, cannot help much since the more it helps the more it will come under pressure itself. The theory of systems competition has nothing but discomforting news in this regard. If only because of the mobility of labor, the welfare states will rather be engaged in a kind of deterrence competition in order to avoid becoming the target of welfare migration.

Yet, at least in western Europe, the welfare state is still intact and will exert its influence on the migration processes involved. This is the theme of this paper. It is about the effects of the welfare state on migration and about possible reforms that may help this state to better deal with the redistributive forces of market integration in general and labor migration in particular. The paper will look at how existing social systems influence immigration and what effect they will exert on the wages of unskilled labor. It will then proceed to identify policy measures that would help improve the economy's reaction including those that enable the welfare state to perform its compensation function despite the forces of systems competition. It assumes a distributional goal for government intervention and investigates the possibilities of achieving this goal with the smallest possible loss of utility or income for other groups of society.

The existing fiscal competition literature is complemented in various ways. Where that literature deals with the reaction of welfare states to migration, it typically models the welfare state as an institution that pays wage subsidies that are added to the wage and increase the incentive to migrate into an otherwise well functioning economy with a flexible labor market. ${ }^{2}$ However, the true welfare state of the European type differs substantially from this. It offers social replacement incomes to those who do not work rather than paying out wage subsidies. Such replacement incomes make wages rigid, unable to react to the competitive forces. It will be shown that replacement incomes bring about reactions to the migration pressure that are dissimilar to the wage subsidies studied in the literature, ${ }^{3}$ notwithstanding the fact that such subsidies would indeed be better tools of the welfare state if combined with a Principle of Selectively Delayed Integration, as will be shown below.

This investigation is phrased in terms of labor migration, because this is where policy interferes most with market forces. On the one hand, governments impose constraints on migration. On the other, the redistributive fiscal measures of the state automatically act 
as welfare magnets for the poor. If the full gains from trade in goods and factors do not materialize in reality it is mostly because government actions distort the labor market. Nevertheless, this study is fully compatible with the other forces that work towards factor price equalization, provided they are not as perfect as in textbook models. It is therefore assumed in this paper that labor migration cannot be fully substituted by commodity trade and capital movements and indeed makes a contribution to improving the efficiency of the international allocation of resources.

\section{The Basic Model}

To concentrate on the complications of the welfare state measures, the model assumes an extremely simple competitive economy as described in the seminal paper by Wildasin (1991). The economy produces a homogeneous traded good with only one factor, labor, by means of the production function $f(L)$ with normal properties. Workers, the "poor", earn the wage $w$ that equals the marginal product of labor, $f^{\prime}(L)=w$. The rich who own an immobile factor, say land, earn the remaining income $f-f^{\prime}(L) L$. Little would change in the model if other mobile factors such as capital were assumed in addition, provided that the immobile factor would still be owned by the rich. Domestic labor of the amount $\bar{L}$ is inelastically supplied and so is the immobile factor.

Similar conditions hold in the rest of the world. Let $\varphi\left(L^{*}\right)$ be the corresponding production function abroad such that $\varphi^{\prime}\left(L^{*}\right)=w^{*}$ determines the set of equilibrium combinations of foreign employment and wage. Let $\bar{L}^{*}$ be the initial foreign labor endowment. When $X$ denotes the stock of migrants in the domestic country and markets clear, then $L=$ $\bar{L}+X, L^{*}=\bar{L}^{*}-X$.

The domestic country is the high-wage country facing immigration pressure. Assume therefore that, when migration is prohibited, $\bar{w}<\bar{w}^{*}$, where $\bar{w}$ and $\bar{w}^{*}$ are the autarky wages defined by $f^{\prime}(\bar{L})=\bar{w}$ and $\varphi^{\prime}\left(\bar{L}^{*}\right)=\bar{w}^{*}$. (Recall that currently, the countries under consideration being, say, west Germany and the new east European EU countries, $\bar{w}$ is seven times as large as $\bar{w}^{*}$.) The domestic country faces an upward sloping migrant supply curve relating the stock of immigrants to its own wage. The curve is upward sloping for two reasons. First, the more people come, the scarcer becomes labor abroad and the higher therefore the foreign wage of the migrants. Second, as people with low migration costs will come first, the marginal cost of migration will be the higher the more have already come.

To model migration costs, think of the European type of commuter migration rather than the American type of permanent immigration. Assume therefore that migration costs are a flow that accrues as long as the migrant lives in the host country. The costs include the cost of regular home travel, of having to pay higher rent in the host country or simply of suffering from homesickness. Let $\psi(X), \psi(0)=0, \psi^{\prime} \geq 0, \psi^{\prime \prime}>0$, be the aggregate migration cost as a function of the stock of migrants such that $\psi^{\prime}(X)$ is the migration cost of an additional migrant if $X$ people have already come. ${ }^{4}$ Then, with open borders, the migration equilibrium and the corresponding wage $w_{C}$ are given by

$$
f^{\prime}(\bar{L}+X)=w_{C}=\varphi^{\prime}\left(\bar{L}^{*}-X\right)+\psi^{\prime}(X) .
$$




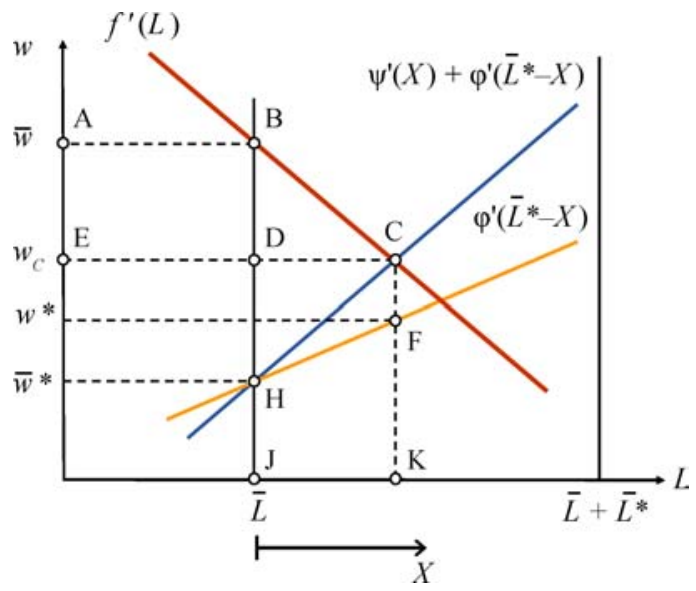

Figure 1. Efficient immigration.

Obviously this migration equilibrium is efficient. Market forces determine the stock of migrants such that international welfare $W$, defined as the joint GDP net of the aggregate migration cost,

$$
W=f(L)+\varphi\left(\bar{L}^{*}-X\right)-\psi(X),
$$

is maximized with regard to $X$, assuming for the time being that $L=\bar{L}+X$, i.e. that all immigrants are employed. The marginal migrant who is indifferent between coming and staying at home expects a wage increase that just equals his migration cost. As wages equal marginal productivities at home and abroad, the wage increase equals the increase of the joint GDP, and hence with the marginal migrant the increase in the joint GDP is just enough to balance the additional migration cost. International welfare is at its maximum.

Figure 1 illustrates the equilibrium. The downward sloping curve is the labor demand curve and the upper of the upward sloping curves is the migrant supply curve. The demand curve represents the marginal product of labor, and the supply curve represents the foreign wage plus the marginal migration cost. When the border is closed, the domestic wage rate is $\bar{w}$ or BJ. Opening the border leads to immigration until the point of intersection $\mathrm{C}$ of the two curves is reached. Immigration is then $\mathrm{JK}$, the domestic wage is $w_{C}$ or $\mathrm{CK}$, and the foreign wage is $w^{*}$ or FK. Despite migration, there remains a wage difference equal to $\mathrm{CF}$ due to the migration cost.

Migration generates a welfare gain because all economies involved are now better off. Domestic output increases by BCKJ, but as the wage bill of the migrants is only DCKJ, there is a surplus BCD for domestic residents. And while foreigners have an aggregate migration cost $\mathrm{HCF}$ and face an output loss equal to HFKJ, the wage income they earn in the host country is DCKJ. Thus they collect a migration rent equal to DCH.

The social problem resulting from this development is the decline in the domestic wage, the income of the poor, from $\bar{w}$ to $w_{C}$. Since firms would replace expensive nationals with cheap migrants if domestic wages did not decline, the wage of the nationals will fall from $\bar{w}$ 
to $w_{C}$. This implies a redistribution of income from poor to rich nationals in the amount of ABDE: The rich will not only capture the gain BCD from employing cheap migrants, but will also enjoy the redistribution gain. The pie becomes bigger, but many people will get an absolutely smaller piece. This is the problem of market integration as perceived nowadays in the industrialized countries. The welfare gain is accompanied by absolute losses for a large part of society, if not the majority.

Proposition 1. Migration costs will bring immigration from the low wage country to a halt when the wage difference equals the marginal migration cost. Free migration maximizes the combined GDP of the countries net of migration cost. The "poor" workers in the industrialized countries nevertheless lose, and "rich" residual claimants gain more than the workers lose.

\section{Fixing Replacement Incomes}

Let us now consider the role of the welfare state, which under realistic conditions pays social replacement incomes to those who do not work. In the past, social replacement incomes like unemployment benefits and welfare payments have largely followed the evolution of wages. Unemployment benefits did so automatically, and welfare payments were adjusted by political decisions. Both represent lower bounds on wages, which hamper the market adjustment to immigration and lead to a different development of the labor market from that described in Figure 1.

Western governments have tended to defend replacement incomes despite the wage inflexibility this has created. In Germany, for example, the government has even increased welfare much faster than average wages over the last three decades with the consequence of creating mass unemployment among the less skilled and making the country world champion in this regard (Sinn, 2003). As mentioned in the introduction, this kind of reaction has little resemblance with the kind of government interventions considered in the fiscal competition literature.

Let $R$ be the replacement income per person offered by the government. The replacement income is financed with taxes on the rich. Assume for the moment that the replacement income is available to nationals as well as immigrants. This assumption will be relaxed in the next section. Let $R \geq w_{C}$ so that the replacement income is effectively binding domestic wages from below. No one will be willing to work for a wage that is lower than what the government pays for not working, and the government pays more than the market would have determined after immigration. Under these conditions, the number of available jobs will not be sufficient to accommodate the migrants. This is so a fortiori, as the replacement income will also act as an immigration magnet, attracting more workers than would have come under a pure market solution. The migration equilibrium is now given by

$$
f^{\prime}(L)=R=\varphi^{\prime}\left(\bar{L}^{*}-X\right)+\psi^{\prime}(X) .
$$

Replacement incomes result in immigration into unemployment, as the work force available in the domestic country is $\bar{L}+X$, while the workers' incentive constraint $w \geq R$ implies that $L<\bar{L}+X$ when $R>w_{C}$. Figure 2 illustrates the equilibrium with points $\mathrm{B}^{\prime}$ and $\mathrm{T}$. 


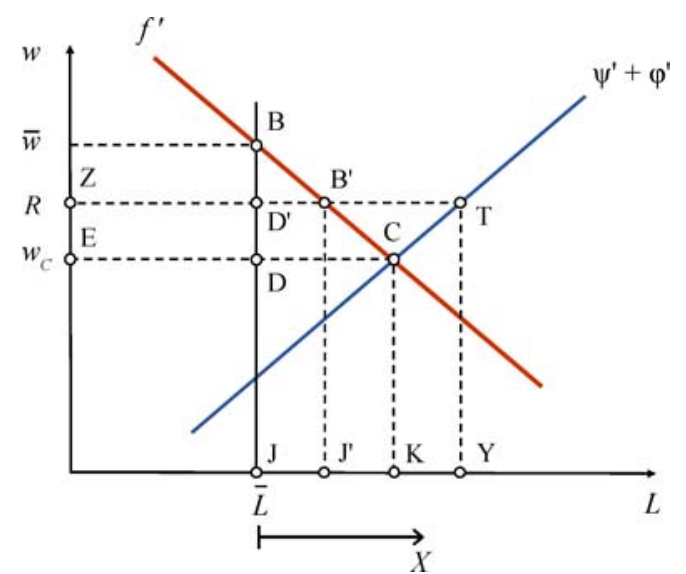

Figure 2. Replacement incomes: Migration into unemployment.

The equilibrium deviates substantially from the efficient immigration equilibrium shown in Figure 1 and characterized by point C. On the one hand, employment is lower implying a comparative output loss of size $\mathrm{B}^{\prime} \mathrm{CKJ}^{\prime}$. On the other hand, immigration is higher by the amount KY. Higher immigration implies less production abroad and higher migration costs. The sum of these two disadvantages relative to the optimum is shown by the area CTYK. Thus, the total welfare loss relative to the efficient migration pattern is $\mathrm{B}^{\prime} \mathrm{CTYJ}^{\prime}$.

The only advantage of this kind of government intervention is that it succeeds in defending the living standard of the poor. However, the disadvantage is a double welfare loss insofar as the policy destroys jobs at home and nevertheless brings in additional workers from abroad. It would obviously always be better from an international welfare perspective to defend a certain wage of the domestic poor by immigration controls than by using a replacement strategy. If the replacement strategy would effectively defend the autarky wage, $R=\bar{w}$, it would be so catastrophic that it would even be better to keep the borders closed. While migrants would add nothing to the domestic GDP in either case, the migration costs and the foreign output loss due to the emigrating labor could be avoided.

Proposition 2. Defending low domestic wages with replacement incomes prevents the creation of additional jobs for the migrants and attracts more immigrants than would have come in a laissez faire equilibrium. There is immigration into unemployment. From an international welfare perspective, the policy is worse than supporting the same wage of the poor by means of immigration controls because it lures people away from productive foreign activities without providing them with additional domestic jobs.

The welfare loss is huge also relative to the budget cost of the replacement incomes. In the figure, the budget cost is equal to $\mathrm{B}^{\prime} \mathrm{TYJ}^{\prime}$. This differs from the international welfare loss only by the triangle $\mathrm{B}^{\prime} \mathrm{TC}$, and this triangle is relatively smaller the less the replacement income $R$ deviates from the undistorted equilibrium wage $w_{C}$. In fact, in the limit, as $R$ approaches $w_{C}$ from above, the relative size of the triangle shrinks to zero. 
A more precise analysis that looks at the marginal impact of a change in $R$ on the international welfare cost and the budget is as follows. The government's budget cost under the replacement strategy, $B_{R}$, is given by

$$
B_{R}=R \cdot \Omega(R)
$$

where

$$
\Omega(R)=\bar{L}+X(R)-L(R)
$$

is the level of unemployment as a function of $R$ with $X(R)$ and $L(R)$ denoting the implicit effect on migration and domestic employment of $R$ as given by (3). Obviously, it follows from equation (3) that

$$
L^{\prime}(R)=\frac{1}{f^{\prime \prime}(L)}<0
$$

and

$$
X^{\prime}(R)=\frac{1}{\psi^{\prime \prime}(X)-\varphi^{\prime \prime}\left(\bar{L}^{*}-X\right)}>0 .
$$

Differentiating equation (4) with respect to $R$ using (5) yields

$$
\frac{\mathrm{d} B_{R}}{\mathrm{~d} R}=\Omega+R \cdot\left(X^{\prime}(R)-L^{\prime}(R)\right),
$$

and differentiating the international welfare function (2) with respect to $R$ (where it is no longer true that $L=\bar{L}+X$ ), taking account of (3), yields

$$
\begin{aligned}
\frac{\mathrm{d} W}{\mathrm{~d} R} & =f^{\prime}(L) L^{\prime}(R)-\left(\varphi^{\prime}\left(\bar{L}^{*}-X\right)+\psi^{\prime}(X)\right) X^{\prime}(R) \\
& =-R \cdot\left(X^{\prime}(R)-L^{\prime}(R)\right) .
\end{aligned}
$$

It follows from (6) and (7) that the marginal welfare effect of an increase in the government's expenditure resulting from an increase in the replacement income $R$ is given by

$$
\frac{\mathrm{d} W}{\mathrm{~d} B_{R}}=\frac{-1}{1+\frac{\Omega}{R \cdot\left(X^{\prime}-L^{\prime}\right)}} .
$$

In the limiting case where the replacement income equals the wage in a first best migration equilibrium and where there is hence no unemployment, $\Omega=0$, this derivative simplifies to:

$$
\frac{\mathrm{d} W}{\mathrm{~d} B_{R}}=-1 \quad \text { for } R=w_{C} .
$$

It follows by continuity arguments that a "small" effective replacement strategy to protect domestic wages incurs a welfare loss that is equal to its budget cost. What this means is that if God provided the national government with an additional euro to be spent on replacement incomes, the domestic and foreign private sectors as a whole would not be better off in terms of a Kaldorian efficiency view. Private agents would change their behavior in such a way as to destroy exactly one euro of economic resources. 
It may also be useful to translate this into the more familiar notion of the marginal cost of public funds, $M$. Suppose the government gains an additional euro by curtailing replacement incomes $\left(\mathrm{d} B_{R}<0\right)$. The marginal cost of this euro to the private sector is the liquidity cost plus the marginal welfare loss which in the present case is negative, however. It follows from (9) that the marginal cost of raising public funds by a cut in replacement incomes is given by:

$$
M \equiv 1+\frac{\mathrm{d} W}{\mathrm{~d} B_{R}}=0 \quad \text { for } R=w_{C} .
$$

Thus there are no private costs in the efficiency sense if the government gains funds by curtailing a small replacement program. Instead of running a small replacement income program it could throw away the money that otherwise would have been given to the unemployed, and the private sector as a whole would not be worse off. This, too, demonstrates how absurd the replacement strategy is from an efficiency point of view.

Proposition 3. The international welfare loss of a small program of social replacement incomes is about equal to the budget cost of this program, and the marginal cost of raising public funds by curtailing such a program is zero from an international welfare perspective.

Rather than from an international welfare perspective, the problem might also be studied from a national welfare perspective. Unlike (2), national welfare, $W_{n}$, is national output minus the income earned by foreigners, which is either the replacement income or a wage of the same size if the replacement income is a binding constraint on wages:

$$
W_{n}=f(L)-R \cdot X, \quad R=w, \quad \text { for } R \geq w_{C} .
$$

It was shown above that, from an international welfare perspective, the replacement strategy is inferior to a policy of immigration controls that defends the same wage. Equation (11) makes it clear that the same holds true from a national welfare perspective. While domestic employment $L$, domestic output and the payment per immigrant, $w$ or $R$, respectively, would be the same, immigration controls trivially imply less immigration and hence lower national expenses for foreigners than a replacement strategy that brings about the same living standard for the domestic poor. National welfare is higher.

To calculate the marginal effect on national welfare of a budget expansion, note that, because of (3), the derivative of (11) with respect to $R$ can be expressed as

$$
\frac{\mathrm{d} W_{n}}{\mathrm{~d} R}=-R \cdot\left(X^{\prime}(R)-L^{\prime}(R)\right)-X
$$

The first term of this equation measures the additional expenses resulting from the increase in unemployment, given $R$, and the second term measures the increase in the migrants' replacement income or wage, given the number of migrants. Because of (3) and (6), and analogously to (8), one gets

$$
\frac{\mathrm{d} W_{n}}{\mathrm{~d} B_{R}}=-\frac{X+R \cdot\left(X^{\prime}-L^{\prime}\right)}{\Omega+R \cdot\left(X^{\prime}-L^{\prime}\right)} .
$$

This expression takes on a value of -1 if the government defends the pre-immigration wage, $R=\bar{w}$, for in that case immigration goes fully into additional unemployment, $X=\Omega$. 
For smaller values of $R$, however, the expression is even more strongly negative, since $\Omega$ shrinks faster than $X$ if the economy approaches the first best equilibrium as given by point $\mathrm{C}$ in the figure. Thus, if God provided the government with an additional euro in a situation where unemployment is less than immigration, not only would the euro be wasted on a payment for unemployment, but in addition, nationals would lose because the euro would be used to bid up the wages earned by immigrants at the expense of their national employers. Thus the gift of a euro to the national government that the government then uses to expand its replacement program would make nationals worse off from a Kaldorian efficiency perspective.

Translated into a national concept of the marginal cost of public funds, $M_{n}$, similar to (10), it follows that

$$
M_{n}\left\{\begin{array}{l}
= \\
<
\end{array}\right\} 0 \Leftrightarrow R\left\{\begin{array}{l}
= \\
<
\end{array}\right\} \bar{w}, \quad R \geq w_{C} .
$$

Thus, from a national perspective, the marginal cost of public funds is zero when the government begins to dismantle a replacement income that equals the autarky wage, and the marginal cost will even be negative if a less extensive replacement wage strategy is pursued. This is the world of Cockaigne for a government that pursues the rules of optimal tax theory. When public funds were taken away from the replacement program to finance the provision of public goods, private nationals would be strictly better off even if the public goods were perfectly useless. Alternatively, the government could use the money saved to make lump sum gifts to foreign residents which would not affect the migration volume, and yet domestic residents as a whole would be better off.

The result can be demonstrated in Figure 2. Suppose the government completely abolishes the replacement program such that the economy moves from points $\mathrm{B}^{\prime}$ and $\mathrm{T}$ on the labor demand and supply curves towards the intersection point $C$ and uses the budgetary funds set free for purposes that do not provide utility to nationals. In this case nationals would nevertheless gain, because the rent from employing foreigners at a wage that equals the marginal product of labor would rise. Before the abolition of the replacement program, this rent is $\mathrm{BB}^{\prime} \mathrm{D}^{\prime}$. After its abolition it is $\mathrm{BCD}$. Thus nationals enjoy a Kaldorian welfare gain equal to $\mathrm{D}^{\prime} \mathrm{B}^{\prime} \mathrm{CD}$, notwithstanding the fact, of course, that there is a redistribution from poor to rich nationals of size $\mathrm{ZD}^{\prime} \mathrm{DE}$.

Proposition 4. With free migration the national welfare loss of a program of social replacement incomes exceeds the budget cost of this program. The national marginal social cost of public funds gained by curtailing such a program is negative if the program is less generous than necessary to defend the autarky wage. If the replacement program is generous enough to support the autarky wage, the marginal national welfare loss from spending money on the program is minus one, and the national marginal social cost of public funds gained by curtailing the program is zero. Also, trivially, from a national welfare perspective the replacement strategy is inferior to immigration controls as a tool to defend the national wage of low-income workers. 


\section{Excluding the Non-Working Migrants}

Thus far it has been assumed that migrants are fully included in the welfare measures of the state, in particular that they have full access to the replacement incomes offered by the government. This is not typically the case, however, since most states do not allow foreigners to directly immigrate into their welfare systems. For example, according to EU rules, welfare benefits and similar replacement incomes are limited to workers. Those who immigrate without working, will not, in general, be entitled to social aid or other replacement incomes. It is true that the inclusion rules as defined in the new EU Constitution of June 2004 and the EU Directive on Free Movement of May 2004 have become much more generous in this regard recently. Nevertheless, at least in the past, only workers were given full access to the benefits of the welfare state.

At first glance, it might seem that with this modification a much more favorable migration pattern would result. For example, one might suspect that in Figure 2 immigration would only be $\mathrm{JJ}^{\prime}$, since additional workers find no jobs, or that only some of the $\mathrm{J}^{\prime} \mathrm{Y}$ immigrants not needed by the labor market would come since they would weight, in a Harris-Todardo fashion, the domestic wage with the probability of finding a job, where the probability is given by one minus the unemployment rate. However, such considerations do not apply since the welfare state is available to the domestic unemployed.

In general, labor markets do not ration employment by seniority rules or randomly, but inversely to the reservation wages. The labor market functions just like any other market. Given the market price, the high cost suppliers, whose average variable cost is above the market price, are out, while the low cost suppliers whose average variable cost is below that price, are in.

When the government limits the payment of replacement incomes to domestic workers, these workers have a reservation wage equal to the replacement income. They are the high cost suppliers who are rationed first. By contrast, the immigrants, who are not eligible for welfare, have lower reservations wages, determined by the sum of the foreign wage and the marginal migration cost. Thus, all immigrants find jobs, and domestic workers service whatever is left of the firms' aggregate demand. The remainder of the domestic workers becomes unemployed.

Figure 3 illustrates this. The figure resembles Figure 2, but explicitly draws in the market supply curve for the domestic labor market. With the given replacement income $R$, domestic workers have a horizontal labor supply curve up to their capacity constraint $\bar{L}$. The JY immigrants, though, all have lower reservation wages, as depicted by the immigration labor supply curve HT. This segment of the immigrants' labor supply curve therefore constitutes the inframarginal part $\mathrm{H}^{\prime} \mathrm{T}^{\prime}$ of the aggregate labor supply curve. After this segment comes a horizontal stretch, $\mathrm{T}^{\prime} \mathrm{T}=\bar{L}$, which reflects the domestic workers' segment of the supply curve. Thereafter, to the right of $\mathrm{T}$, the aggregate supply curve continues with those foreign workers who, because they have reservation wages above $R$, do not migrate. It follows that only $\mathrm{T}^{\prime} \mathrm{B}^{\prime}$ domestic workers are employed, and $\mathrm{B}^{\prime} \mathrm{T}$ domestic workers are being crowded out into unemployment.

There still is immigration into unemployment triggered by the welfare state, but it is indirect immigration, pushing domestic residents out of their jobs. In order for the economy 


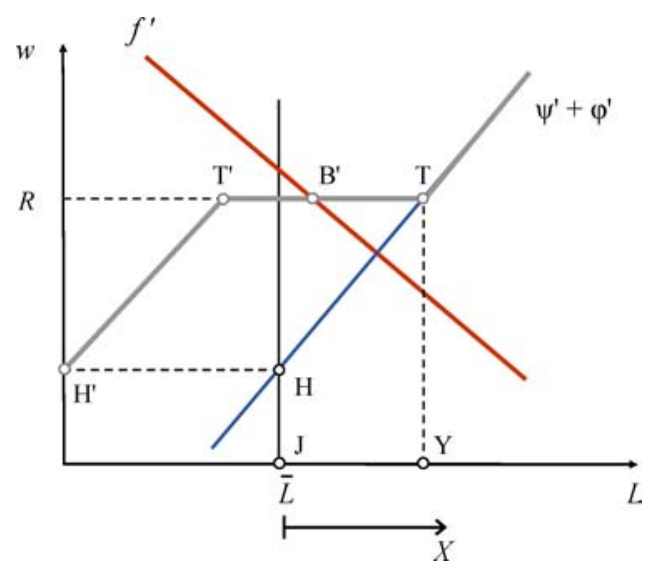

Figure 3. Replacement incomes only for domestic residents: Indirect immigration into unemployment.

to create jobs for the immigrants, wages would have to fall, but they cannot do so because the fixed replacement income offered by the government makes domestic workers the marginal suppliers in the market. Rather than participating in low wage competition with the migrants, nationals will accept to be seated in the easy chair offered by the welfare state, but as long as not all of them are crowded out by the migrants, they will stay the marginal suppliers and prevent the wage rate from falling after immigration.

To avoid crowding out nationals, a combination of wage freeze and dismissal protection is sought in most industrialized countries. In theory, this could reverse the market rationing scheme and it could protect the domestic workers by effectively differentiating wages similar to a price discriminating monopolist. However, this can at best be a temporary solution since despite dismissal protection there is a natural exchange in the labor market due to stochastic personal events that force people to quit jobs or due the normal generational exchange of the workforce. The flow of domestic residents offering their services in the labor market will go directly into unemployment before the wage can fall due to the competition of immigrants. Only if the flow of immigrants is larger than the flow of new domestic workers seeking jobs, will there be a pressure on wages that could possibly create more jobs. However, this is an unlikely condition. In Germany, for example, 7 million people per year lose their jobs and 7 million find new ones, but the flow of immigrants is in the order of only a few hundreds of thousands.

Within the present model, the limited inclusion rights of foreigners have no welfare implications, and in fact they imply no modifications of any of the equations set up above. As the wage that lures the migrants still equals the replacement income $R$, the size of migration is the same as before. The assumption that the immigrants rather than the nationals suffer from unemployment was never needed, and the rationing pattern was indeterminate anyway.

Proposition 5. If immigrants are not eligible for wage replacement incomes, there will be indirect immigration into unemployment in the sense that immigrants crowd out national residents from the labor market. The wage will not be able to fall below the reservation wage 
set by the government, unless all national low-income workers have been crowded out by the immigrants. The welfare analysis of a restriction of replacement incomes to nationals does not differ from the case where non-employed immigrants are fully included.

The identity of the welfare calculation would no longer hold, if domestic residents were assumed to prefer being unemployed and collecting replacement income rather than earning this income with their own work. In that case, there would be a slight advantage from excluding the foreigners from directly migrating into the welfare state. However, the reservation wages of domestic workers would be higher and even more immigration would be induced. Insofar a less disastrous migration pattern could hardly be expected than the one described by the model.

The reality of welfare states speaks a clear language in this regard. Germany, for example, had immigration of 7.6 million people from 1970 to 2002 of which about 3.1 million entered official employment. At the same time, mass unemployment occurred. Whereas there had hardly been any unemployment in $1970(150,000)$, by 2002 unemployment among nationals had increased by 3.2 million people. Although no proof, the coincidence between these numbers is remarkable. It fits the very generous German system of social aid that provides an income for a family of four that is more than four times the Polish wage. It also fits the observation that Germany had quadrupled its welfare level from 1970 to 2000 while industrial wages in the same period of time had "only" tripled. With the generous expansion of the welfare state since the 1970s, Germany compressed its wage scale from below while the country experienced mass immigration. Small wonder that mass unemployment resulted.

\section{Wage Subsidies}

Social replacement payments are made to individuals on condition that they do not work. Thus it should not be surprising that the welfare implications are so unfavorable.

Subsidies which are not conditioned on idleness might be a better means to protect domestic workers from the forces of low wage competition. As mentioned in the introduction most of the literature on welfare state competition has modeled the welfare state as an institution that pays subsidies to the poor and recently Drèze (2002) has advocated subsidies as a means to defend European workers against the forces of globalization. Let $S$ be a personal subsidy like the US Earned Income Tax Credit which is available to a low income worker and assume for the time being that this subsidy is provided to nationals and immigrants alike. If applied in Europe, this assumption would reflect the strict non-discrimination rules of the EU that allow for a distinction between employed nationals and non-employed immigrants, but not between employed nationals and employed immigrants. Then, instead of (1) or (3) the migration equilibrium is given by

$$
f^{\prime}(\bar{L}+X)+S=\varphi^{\prime}\left(\bar{L}^{*}-X\right)+\psi^{\prime}(X),
$$

where the market wage under the subsidy scheme satisfies the condition $f^{\prime}(\bar{L}+X)=w_{S}$ and a worker's income including the subsidy is $\bar{w}_{S}=w_{S}+S$.

This policy measure does not create unemployment, but since it raises the income of workers above the marginal product of labor, it attracts additional workers from abroad. 


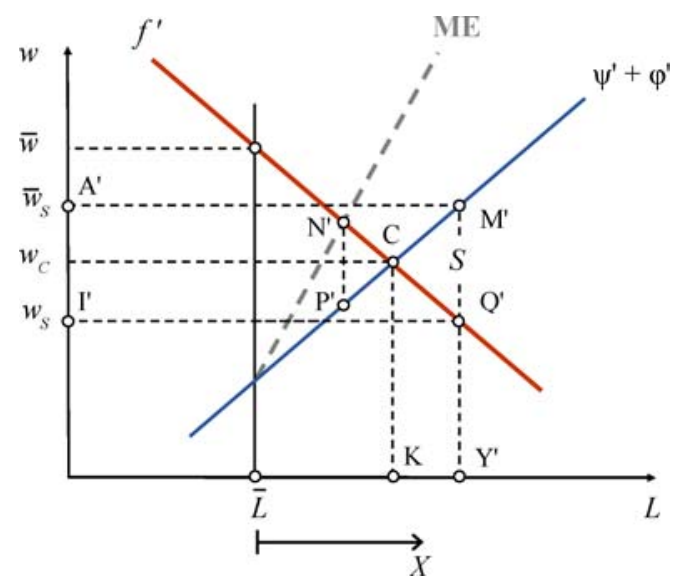

Figure 4. Wage subsidies.

Only to the extent that the reservation wages of these workers are being pushed up due to an increased labor scarcity abroad and increased marginal migration costs will the policy succeed in raising or defending the standard of living of the national poor.

Figure 4 illustrates the immigration equilibrium. The subsidy drives a wedge of size $S$ or $\mathrm{M}^{\prime} \mathrm{Q}^{\prime}$ between the required marginal compensation of migrants - the sum of the foreign marginal product of labor and the marginal migration cost-and the marginal domestic product of labor. Compared to laissez faire, it induces additional immigration $\mathrm{KY}^{\prime}$. While the domestic wage falls from $w_{C}$ to $w_{S}$, the income of domestic workers rises to $\bar{w}_{S}$. With a sufficiently generous subsidy it would be possible to fully protect the incomes of domestic workers from the competition of migration, pushing them back to the autarky level $\bar{w}$.

From an international welfare perspective, the subsidy strategy seems less problematic than the replacement strategy since employment is higher and no human resources are wasted. However, there is a welfare loss insofar as immigration exceeds the optimum, which means that the additional migrants produce less in the host country than would be required to compensate for the loss in foreign production plus the migration cost. In Figure 4 , the welfare loss is given by the triangle $\mathrm{CM}^{\prime} \mathrm{Q}^{\prime}$.

Figure 4 suggests that the welfare loss is small relative to the budget cost $\mathrm{A}^{\prime} \mathrm{M}^{\prime} \mathrm{Q}^{\prime} \mathrm{I}^{\prime}$ when $S$ is small. To verify this, consider the budget cost

$$
B_{S}=S \cdot(\bar{L}+X(S))
$$

where $X(S)$ is the functional relationship between $S$ and $X$ as implied by (12) which satisfies

$$
X^{\prime}(S)=\frac{1}{\psi^{\prime \prime}(X)-f^{\prime \prime}(\bar{L}+X)-\varphi^{\prime \prime}\left(\bar{L}^{*}-X\right)}>0
$$

Differentiating (13) and the welfare function (2) with respect to $S$, using (12) and (14). yields

$$
\frac{\mathrm{d} B_{S}}{\mathrm{~d} S}=L+S \cdot X^{\prime}(S)
$$


and

$$
\begin{aligned}
\frac{\mathrm{d} W}{\mathrm{~d} S} & =\left(f^{\prime}-\varphi^{\prime}-\psi^{\prime}\right) \cdot X^{\prime}(S) \\
& =-S \cdot X^{\prime}(S) .
\end{aligned}
$$

Using (12), these two equations together can be shown to imply

$$
\frac{\mathrm{d} W}{\mathrm{~d} B_{S}}=-\frac{S \cdot X^{\prime}(S)}{L+S \cdot X^{\prime}(S)} .
$$

In the limiting case where $S=0$ this indeed reduces to

$$
\frac{\mathrm{d} W}{\mathrm{~d} B_{S}}=0 \quad \text { for } S=0
$$

rather than -1 as with the replacement strategy. Accordingly, the marginal cost of raising public funds by curtailing a small subsidy program is one,

$$
M \equiv 1+\frac{\mathrm{d} W}{\mathrm{~d} B_{S}}=1 \quad \text { for } S=0,
$$

rather than zero as before. This is the usual result for small deviations from the first best allocative optimum. As the welfare loss is a second order effect, it can be neglected for small government interventions.

Proposition 6. Wage subsidies can be used to protect the living standard of low income earners, but they imply excessive immigration. Small subsidies involve only second-order international welfare effects such that the marginal international cost of public funds generated by curtailing a small subsidy program is about one.

Things are different from a national welfare perspective. With regard to national welfare, a subsidy strategy is an expensive way to support the workers' wages because the country could try to exploit a monopsony position with regard to the immigrants, and for that purpose a tax on workers rather than a subsidy would be optimal from a Kaldorian efficiency perspective. National welfare is defined as the difference between national output and the wage and subsidy income paid out to migrants:

$$
W_{n}=f(\bar{L}+X)-X \cdot\left(w_{s}+S\right) .
$$

As can easily be demonstrated, the situation where $W_{n}$ is maximized and hence $\mathrm{d} W_{n} / \mathrm{d} B_{S}=$ 0 , is characterized by a negative value of $S$. The dashed marginal expenditure curve ME in Figure 4 sketches the argument showing the optimal tax $\mathrm{N}^{\prime} \mathrm{P}^{\prime}$, i.e. the optimal size of the negative subsidy. Distorting the laissez faire equilibrium with a subsidy for workers would therefore involve a first order rather than a second order welfare loss from a national perspective.

Nevertheless, the subsidy strategy is a more rational strategy than the replacement income strategy to defend the wages of the poor against the competition of migrants for the simple reason that domestic output is higher. Suppose both strategies target the same income level for domestic workers, i.e. suppose that

$$
R=w_{S}+S>w_{C} \quad \text { such that } X(R)=X(S)
$$


In this case both the replacement strategy and the subsidy strategy result in the same migration volume, the same loss in foreign output and the same income earned by foreigners. However, as domestic employment and output is higher with the subsidy strategy, inspection of the welfare functions (2), (11) and (15) shows that both international and national welfare would be higher under the subsidy strategy by the additional domestic output that this strategy allows to be produced.

As output is higher while the income of national workers and migrants is the same, it is clear that the "rich" domestic residual claimants will be better off with the subsidy strategy regardless of which of the strategies has a lower budget cost and hence involves lower taxes on the rich.

Interestingly enough, it also follows immediately from (12), (15) and (16) that migration controls that target the same income for the domestic poor would even be better than subsidies from a national perspective. ${ }^{5}$ Such controls would involve lower domestic output, but as the excluded migrants all have a marginal product below this target income, the output loss would be more than outweighed by the lower income payments to migrants. However, migration controls are no solution to the problem of protecting the income of the poor when there is migration, as was assumed in this paper.

Returning to the comparison between the replacement and the subsidy strategies, it might be interesting to know which strategy will incur the lower budget cost. Comparing (4) and (5) with (13) shows that

$$
B_{S}\left\{\begin{array}{l}
< \\
= \\
>
\end{array}\right\} B_{R} \Leftrightarrow S \cdot(\bar{L}+X(S))\left\{\begin{array}{l}
< \\
= \\
>
\end{array}\right\} R \cdot(\bar{L}+X(R)-L(R)) .
$$

Taking account of (16) and noting that, by assuming equal target incomes for the poor, $X(S)=X(R)$, this expression can be transformed to

$$
B_{S}\left\{\begin{array}{l}
< \\
= \\
>
\end{array}\right\} B_{R} \Leftrightarrow 1\left\{\begin{array}{l}
< \\
= \\
>
\end{array}\right\} \frac{(\bar{L}+X(R)-L(R)) / L(R)}{S / w_{S}} .
$$

Note that the right-hand side of this expression is the absolute value of the elasticity of the firms' labor demand curve: The subsidy strategy is accompanied by a wage rate that is lower by the amount $S$ than with the replacement strategy and generates a higher employment volume, just enough to eliminate the unemployment that would result from the replacement strategy, $\bar{L}+X(R)-L(R)$. Obviously, therefore, the denominator of the expression indicates a relative wage decline and the numerator the corresponding relative employment increase, the ratio of these values being the elasticity of the labor demand curve.

The size of the aggregate labor demand elasticity is not quite clear empirically, and specific elasticities for the low wage sector are particularly scarce. The elasticity level also depends on the time perspective. In the short run it is smaller than in the long run, because in the long run other factors, which have not been included here formally, may also change. In the limiting case, where capital movements and/or Heckscher-Ohlin specialization effects are sufficient to bring about factor price equalization, the labor demand elasticity would even be infinite. As a rule of thumb, the elasticity is about unity in the medium term and greater than one in the long term perspective. ${ }^{6}$ This in itself suggests that the subsidy 
strategy will be accompanied by the same or even smaller budget costs than the replacement strategy.

Proposition 7. From a national perspective, wage subsidies are problematic means to defend the income of the poor, since wage taxes would allow the country to exploit a monopsony position relative to the emigration countries. Yet, the subsidy strategy clearly outperforms the replacement strategy insofar as, with a given income being secured for the poor, both national and international welfare will be higher. When the elasticity of labor demand is above unity in absolute terms, the subsidy strategy will even be cheaper for the government. From a national welfare perspective, migration controls dominate subsidies and replacement incomes as measures to defend the income of the poor.

\section{Selectively Delayed Integration and Home Country Principle}

While migration controls dominate the subsidy strategy in terms of defending the income of the national poor with a minimum cost to other groups of the society, they imply throwing the baby out with the bathwater. The gains from trade that market integration promises would not be available with such a measure. A yet better strategy that outperforms all policy measures considered thus far is to differentiate incomes between immigrants and nationals by paying the wage subsidies to nationals only. Dismissal protection plus wage freeze is one way of differentiation, but as argued above, it does not work well because of natural job fluctuation. A differentiation by nationality, on the other hand, would be easier to administer and compatible with a liberal labor market regime.

The Principle of Selectively Delayed Integration of employed immigrants has been suggested for this purpose. ${ }^{7}$ According to this principle, immigrant workers do pay their taxes and social security contributions, they receive all contribution-financed social benefits, and they have free access to the public infrastructure. However, during some initial waiting period some of the tax-financed social benefits are excluded so as to avoid making gifts to the migrants. In addition, the Home Country Principle could be used for welfare payments to non-employed immigrants, which means that these immigrants would have to claim support from the emigration country if they are needy. ${ }^{8}$

Such a solution would obviously be compatible with a first best migration equilibrium as depicted in Figure 1, since it would not interfere with the marginal conditions of that solution. The redistribution loss ABDE resulting from the competition of migrants could be avoided by paying the subsidy to the nationals only. The government could effectively compensate the losers of market integration without making them the marginal, high-cost suppliers in the labor market. The tax revenue needed to finance this compensation would be levied on the rich. The rich would nevertheless gain from market integration because they could capture the rent $\mathrm{BCD}$ from employing the migrants, and the foreigners would receive their migration rent $\mathrm{DCH}$ as was explained above. If the same income of the domestic poor were to be ensured by an immigration control, none of these two rents would accrue. Both countries' national welfare would be lower. Aggregate welfare would be lower by the area BCH in Figure 1. ${ }^{9}$ 
Proposition 8. A simple and efficient way to defend the incomes of the poor against the low-wage competition of migrants would be the payment of wage subsidies coupled with the policy of Selectively Delayed Integration for employed migrants (and the Home Country Principle for non-employed migrants). National and international welfare would be higher than with migration controls defending the same income of the domestic poor.

\section{Concluding Remarks}

This paper has analyzed the possibilities to defend the wages of the poor against the lowwage competition of migrants. Defending social standards or replacement incomes were shown to be very inefficient ways for the government to proceed. The maintenance of standards makes the poor worse off than without government action, and replacement incomes are so extremely inefficient that the marginal cost of raising public funds by dismantling them would be close to zero from an international, and even negative from a national, welfare perspective. Wage subsidies, if possible ones that are restricted to the domestic population, turned out to be much better alternatives from the point of view of economic efficiency and the size of the government expenses necessary to defend a given income level.

As has been pointed out elsewhere, wage subsidies that are limited to nationals would, in addition, have the advantage of not being eroded by the forces of systems competition. As migrants do not cause public resource costs, there would be no incentive for governments to participate in a game of deterrence with regard to migration flows.

There would, however, be legal problems when it comes to intra-EU migration. Currently, EU rules forbid the discrimination of employed immigrants by excluding them from some of the benefits the welfare state is offering. It is true that the UK and Ireland have succeeded in negotiating exclusion rules before agreeing to the draft of the new EU constitution. However, Article II 94 of that constitution explicitly excludes similar exceptions in the future. It remains to be seen whether the new constitution will be ratified by the countries of Europe. If so, the discrimination strategy would no longer be feasible. In that case only the other solutions discussed in this paper would remain. Basically this means that the replacement strategies should be abandoned. Only a limited program of income subsidies to the poor would be compatible with a roughly efficient migration pattern in Europe.

\section{Acknowledgment}

The author wishes to thank an anonymous referee and the editor, Jay Wilson, for useful comments.

\section{Notes}

1. For a more extensive discussion of the economic consequences of these huge wage differences see Sinn (2003, chapters 2 and 8 ). 
2. See, e.g., Brown and Oates (1987), Wildasin (1991, 1994), Cremer and Pestieau (1996), Wilson (2004) and the literature survey by Brueckner (2000).

3. See also the non-technical treatment of the theme in Sinn (2003). Sinn and Ochel (2003) discuss replacement incomes and social standards from the viewpoint of EU harmonisation measures imposed upon accession countries.

4. While the paper will only analyze cases where $X$ is positive, the specification as such will also hold for negative $X$, which indicates west-east migration.

5. See Wilson (2004) for a comparison of migration controls and subsidies in a similar model framework.

6. See Burgess (1988), Franz and König (1986) or Nickel and Symons (1990).

7. Wissenschaftlicher Beirat beim Bundesministerium der Finanzen (2001), Sinn et al. (2001), Sinn and Werding (2001), Sinn (2002), and in particular the theoretical analysis by Richter (2004).

8. Sinn (1990, 2002). See also an extensive treatment of this issue in the context of EU legislation in Sinn (2003).

9. Wilson (2004) found that under certain conditions a combination of migration controls and subsidies would yield more migration and higher welfare than subsidies alone if general equilibrium repercussions between the government policies are taken into account. It would interesting to find out whether the dominance of a combination of Selectively Delayed Integration and subsidy payments over migration controls found here would carry over to the Wilson model.

\section{References}

Burgess, S. M. (1988). "Employment Adjustment in UK Manufacturing,” Economic Journal 98, 81-103.

Brown, C. C. and W. E. Oates. (1987). "Assistance to the Poor in a Federal System," Journal of Public Economics 32, 307-330.

Brueckner, J. (2000). "Welfare Reform and the Race to the Bottom: Theory and Evidence," Southern Economic Journal 22, 505-525.

Cremer, H. and P. Pestieau (1996). "Distributive Implications of European Integration," European Economic Review 40, 747-757.

Drèze, J. H. (2002). "Economic and Social Security: The Role of the EU," De Economist 150, 1-18.

Franz, W. and H. König. (1986). "The Nature and Causes of Unemployment in the Federal Republic of Germany since the 1970s: An Empirical Investigation,” Empirica 53, 219-244.

Nickel, S. J. and J. Symons. (1990). “The Real Wage_Employment Relationship in the United States,” Journal of Labor Economics 8, 1-15.

Richter, W. F. (2004). “Delaying Integration of Immigrant Labor for the Purpose of Taxation,” Journal of Urban Economics 55, 597-613.

Sinn, H.-W. (1990). "Tax Harmonization and Tax Competition in Europe," European Economic Review 34, Papers \& Proceedings, 489-504.

Sinn, H.-W. (2002). "EU Enlargement and the Future of the Welfare State," Stevenson Citizenship Lectures, Scottish Journal of Political Economy 49, 104-115.

Sinn, H.-W. (2003). Ist Deutschland noch zu retten? Munich: Econ.

Sinn, H.-W., G. Flaig, M. Werding, S. Munz, N. Düll, H. Hofmann, A. Hänlein, J. Kruse, H.-J. Reinhard, and B. Schulte. (2001). EU-Erweiterung und Arbeitskräftemigration: Wege einer schrittweisen Annäherung der Arbeitsmärkte, ifo Beiträge zur Wirtschaftsforschung 2, Munich: Ifo Institute for Economic Research. English: Sinn, H.-W., G. Flaig, M. Werding, S. Munz, N. Düll, and H. Hoffmann (2003). EU Enlargement and Labour Mobility: Consequences for Labour Markets in Germany and Redistribution by the State. Munich: Ifo Institute for Economic Research.

Sinn, H.-W. and W. Ochel (2003). "Social Union, Convergence and Migration," Journal of Common Market Studies 41, 869-896.

Sinn, H.-W. and M. Werding (2001). "Immigration Following EU Eastern Enlargement," CESifo Forum 2(2), 40-47. 
Wildasin, D. (1991). "Income Redistribution in a Common Labour Market," American Economic Review 81, $757-774$.

Wildasin, D. (1994). "Income Redistribution and Migration," Canadian Journal of Economics 27, 637-656.

Wilson, J. D. (2004). "The Welfare State vs. The Common Labor Market: Which to Dismantle," Mimeo, Michigan State University.

Wissenschaftlicher Beirat beim Bundesministerium für Finanzen (Advisory Board to the Federal Ministry of Finance, Germany) (2001). "Freizügigkeit und Soziale Sicherung in Europa," BMF Schriftenreihe, No. 69, Bonn: Stollfuß Verlag. 